\title{
IMPLEMENTASI KINERJA MESIN PEMOTONG KEMPLANG KHAS PALEMBANG BERBASIS TEKNOLOGI INTERNET OF THINGS (IOT) Slamet Widodo ${ }^{1}$, A.Bahri Joni $\mathbf{M}^{2}$, Ahyar Supani ${ }^{3}$ \\ ${ }^{1}$ Jurusan Teknik Komputer Politeknik Negeri Sriwijaya \\ 2 Jurusan Teknik Komputer Politeknik Negeri Sriwijaya \\ ${ }^{3}$ Jurusan Teknik Komputer Politeknik Negeri Sriwijaya \\ email slametwidodo@polsri.ac.id,bahrijoni@polsri.ac.id, ahyarsupani@gmail.com
}

\begin{abstract}
Abstrak
Palembang adalah kota yang mempunyai sejarah kerajaan Sriwijaya yang sangat terkenal. Diantaranya peninggalan budaya dan wisata kulinernya yang bermacam-macam yang sampai sekarang masih dilestarikan yaitu wisata kulinernya. Salah satu kuliner yaitu kerupuk kemplang. Saat ini pengusaha pembuat kemplang ikan masih banyak menggunakan cara tradisional menggunakan pisau manual dan pirikan kuningan, dengan beragam besar lubang dan potonganya yang tidak sama. Fenomena seperti ini juga dilakukan oleh mitra program DPTM yaitu Mitra (1) Usaha Kerupuk Kemplang "Lebak keranji; Mitra(2) Usaha Kerupuk Kemplang "Matahari 222" di jalan Lunjuk Jaya Bukit Besar Palembang. Beberapa kendala yang dihadapi usaha kerupuk kemplang ke 2(dua) mitra adalah belum adanya mesin pemotong hasil olahan adonan tepung dan ikan untuk pemotongan bahan kerupuk kemplang ikan sehingga memerlukan tenaga pengrajin yang banyak dan membutuhkan waktu cukup lama. Tujuan program pengabdian kemitraan yaitu nntuk mengatasi permasalahan tersebut dipandang perlu mesin untuk mencetak dan pemotong gelondongan kerupuk kemplang menggunakan mesin otomatis. Metode yang digunakan adalah dengan rancang bangun mesin pemotong gelondongan bahan kerupuk yang dikendalikan menggunakan mikrokontroller berbasis IoT( Internet of Things).Hasil dari pelaksanaan kegiatan program kemitraan ini menghasilkan alat yang pemotong kemplang semi otomatis yang dapat di on/off kan secara otomatis dan dapat menghitung jumplah produksi kemplang siap goreng dan pemasaran
\end{abstract}

Kata Kunci : Kerupuk Kemplang ,Mesin Pemotong Kemplang,Mikrokontroller,Internet of Things

\section{PENDAHULUAN}

Palembang merupakan salah satu daerah di Indonesia yang dikenal memiliki kuliner yang bercita rasa khas dan enak. Ibu kota dari Sumatera Selatan ini menyimpan kekayaan kuliner yang sangat beraneka ragam. Dengan sensasi rasa yang gurih, pedas, segar sampai manis dari jajaran kuliner khas Palembang. Selain memiliki cita rasa yang khas, kuliner Palembang juga memiliki cerita tersendiri berkaitan dengan sejarah Kota Palembang dan perkembangan kehidupan masyarakatnya. Kemplang Kerupuk Ikan Palembang merupakan salah satu makanan tradisional khas Palembang dengan bahan dasar ikan dan tepung tapioka.

Pada saat ini pengusaha pembuat kemplang ikan masih banyak menggunakan cara tradisionalnya menggunakan pirikan kuningan, dengan beragam besar lubang pada bagian bawahnya. Fenomena seperti ini juga dilakukan oleh mitra program DPTM yaitu Mitra (1) Usaha Kerupuk Kemplang "Lebak keranji; Mitra(2) Usaha Kerupuk Kemplang "Matahari 222" di jalan Lunjuk Jaya. Proses pembuatan kerupuk kemplang dengan tradisional Seperti pada gambar 1 . berikut ini : 


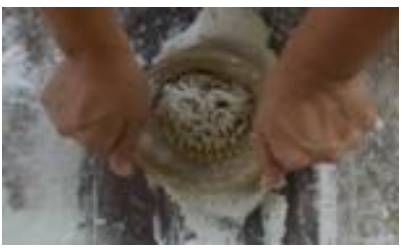

Gambar 1. Alat Pirikan Tradisional Kerupuk Palembang Makanan yang biasa dijadikan oleh-oleh dari Palembang, karena daya tahanya yang lumayan lama. Kerap dijadikan sebagai lauk makan di Palembang atau cemilan. Umumnya terbuat dari ikan yang diolah sedemikian rupa. Perbedaanya pada tekstur, kalau kemplang bertekstur Padat dengan bentuk yang bervariasi, sementara kerupuk berbentuk bulat, berongga-rongga, serta lebih renyah pada gambar 2 berikut ini :

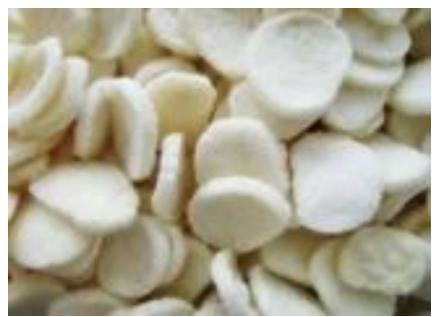

Gambar 2. Hasil Olahan Jenis kerupuk khas Palembang Kerupuk Kemplang Palembang, Sumatera Selatan sangat diminati warga Belanda, terbukti saat mengikuti kegiatan pasar malam di negara tersebut makanan khas itu habis diborong. Kepala Dinas Koperasi dan Usaha Kecil Menengah (UKM) Provinsi Sumsel, H Abdul Shobur di Palembang, saat Indonesia termasuk utusan UKM Sumsel ikut pasar malam ternyata Kerupuk Kemplang paling laris. Bahkan pemasaran Kerupuk Kemplang keluar negeri tersebut untuk melestarikan sekaligus mempromosikan makanan khas Palembang tersebut ke Mancanegara. (kompas.com,2010).

Dalam melaksanakan kegiatan Pengabdian kemitraan ini tim pelaksana melakukan kerjasama dengan 2 (dua ) mitra yaitu pengrajin produksi kerupuk kemplang "Matahari" yang terletak di perumahan Tanjung Barangan dan Pengrajin kerupuk kemplang "Lebak Keranji" di jalan bukit lama Palembang. Dimana lokasi kedua mitra tersebut berjarak kira-kira $3 \mathrm{KM}$ dari Lembaga Litbang Politeknik Negeri Sriwijaya Palembang. Berikut ini gambaran kondisi yang sebenarnya pada ke dua mitra program DPTM setelah dilakukan observasi ke lokasi masing-masing mitra usaha pada gambar 3 dan 4 berikut :

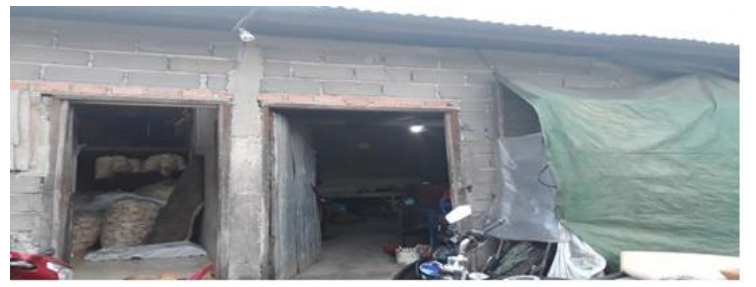

Gambar 3. Lokasi Mitra Pengabdian

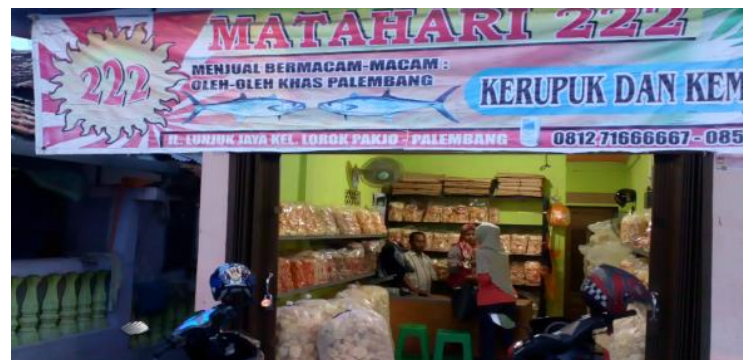

Gambar 3. Toko Kemplang Matahari 222

\subsection{Permasalahan Mitra}

Dari hasil observasi di lapangan serta diskusi dengan pemilik usaha kerupuk kemplang khas Palembang ada beberapa permasalahan proses produksi yang dihadapi oleh mitra diantaranya adalah :

1. Proses pemotongan bahan baku kerupuk kemplang masih menggunaka manual tangan manusia sehingga terkesan lama.

2. Belum adanya mesin pemotong bahan gelondongan bahan baku kerupuk kemplang.

3. Kurang simitris dan terkesan tidak sama hasil potongan bahan baku kerupuk kemplang.

4. Belum adanya mesin penghitung jumlah potongan sehingga jumlah produksi tidak diketahui secara langsung.

5. Kurangnya sumber daya manusia yang mengetahui cara pengoperasian mesin otomatis .

6. Manajemen dan pemasaran yang belum maksimal.

\subsection{Tujuan Kegiatan}

Dari uraian permasalahan yang dijelaskan maka dirumuskan permasalahan mitra adalah 
bagaimanakah merencanakan meningkatkan kemampuan sumberdaya manusia khususnya dalam proses pengoperasian mesin dan meningkatkan infrastruktur alat mesin pemotong bahan gelondongan kerupuk kemplang untuk meningkatkan produksi kerupuk kemplang menjadi lebih maksimal sehingga menciptakan nilai keberhasilan masyarakat menghasilkan produk makanan yang higienis dan sehat untuk mendapatkan kualitas makanan sehat dan halal khususnya kerupuk kemplang Palembang.

\subsection{Rencana Penanganan Permasalahan}

Pada kegiatan ini akan dibuat rancang bangun Mesin Pemotong Kemplang otomatis yang dikendalikan dengan mikrokontroller berbasis IoT.

\section{METODE}

Pada program pelaksanaan kegiatan ini metode yang dilaksanakan yaitu menggunakan langka-langkah analisis situasi mitra, perancangan /desain hardware dan softaware, pengujian mesin dan implementasi sebagai berikut:

Tahapan pelaksanaan kegiatan IPTEKS tentang pembuata pembuatan mesin dan aplikasi produksi pemotongan kerupuk kemplang yaitu pelatihan dengan materi sebagai berikut :

1. Analisa situasi dengan kondisi infrastruktur proses pembuatan pemotongan gelondongan kemplang.

2. Analisa situasi tentang perancangan aplikasi monitoring penghitung jumah produksi bahan gelondongan kerupuk kemplang.

3. Cara membuat rancangan mesin pemotong

4. Cara menjalankan mesin pemotong

5. Cara merancang aplikasi monitoring

6. Cara merancang sensor pada mesin

7. Cara menghidupkan mesin dengan aplikasi

8. Cara mematikan mesin dengan aplikasi

9. Cara memonitoring produksi mesin dengan aplikasi.

\subsection{Tinjauan Pustaka}

2.1.1 Kerupuk Kemplang

Kemplang merupakan salah satu makanan ringan yang digemari masyarakat Indonesia khususnya Sumatra bagian Selatan. Bahan baku utama kerupuk kemplang adalah ikan segar dan tepung tapioca.
Kerupuk kemplang memiliki sifat mudah menyerap uap air dari udara sekitar. Hal tersebut membuat kerupuk kemplang mudah melempem dan teksturnya menjadi lebih alot. (Astrid Wulandari,etc All,2013)

\subsubsection{Mikrokontroller}

Mikrokontrolle Arduino adalah platform prototipe open-source yang dirancang agar mudah digunakan untuk pemula yang tidak memiliki perangkat lunak atau pengalaman elektronik tingkat tinggi. Ini dapat digunakan untuk mengembangkan interaktif objek yang dapat merespon sinyal dari lingkungan sekitarnya. Mikrokontroler ini dapat mengontrol berbagai hal seperti tombol, motor, unit GPS, LED, sensor, kamera dan banyak lagi . Arduino mikrokontroler dapat diprogram menggunakan lingkungan pengembangan terintegrasi Arduino (IDE). Untuk memuat kode baru pada papan Arduino tidak memerlukan perangkat keras terpisah - cukup sambungkan kabel USB. Platform ini digunakan oleh banyak musisi di seluruh dunia untuk membangun proyek elektronik, jadi ada banyak informasi dan kode sumber tersedia. Namun, pengontrol ini juga digunakan oleh banyak Bekerja ilmuwan.(Slamet Widodo,2019).

\subsubsection{Sensor IR}

Percobaan telah menunjukkan bahwa rig sensor IR mampu menangkap data dalam hal jarak antara sensor dan objek. Data yang diterima dari sensor direkonstruksi menggunakan Matlab dan gambar yang telah direkonstruksi mirip dengan objek asli. Perhatian ekstra perlu diambil selama percobaan seperti menjalankan rig sensor di ruang dekat dan posisi objek di tengah rig sensor sama untuk menghindari yang tidak diinginkan sinyal yang dapat menyebabkan kesalahan pada pembacaan IR.( SitiAsmah Daud,etc all,2013)

\section{IoT (Internet of Things)}

Internet of things (IoT) adalah jaringan perangkat naif berkomunikasi satu sama lain melalui internet untuk Melakukan tugas terpadu dengan cara yang lebih cerdas. Arsitektur IoT terdiri secara nirkabel sensor tertanam, node, aktuator dan mikrocontroller untuk melakukan dan mengambil keputusan yang cerdas. Di sini, objeknya, perangkat,

$$
\text { Teknologi Tepat Guna }
$$


mesin, hewan, manusia disediakan unik tag identifikasi yang memungkinkannya untuk diidentifikasi dari area yang terletak jauh dan mentransfer data tanpa perlu HCI (Interaksi Manusia-Komputer). Hiral S. Doshi etc.all(2017)

\subsubsection{Blynk}

Blynk merupakan platform sistem operasi iOS maupun Android sebagai kendali pada modul Arduino, Raspberry Pi, ESP8266 dan perangkat sejenis lainnya melalui internet. Handi etc All (2019)

\subsubsection{Motor Listrik}

Suatu motor listrik mampu mengubah energi listrik menjadi energi mekanik melalui media elektromagnet, motor listrik inilah yang menjadi penggerak pada sistem transportasi ramah lingkungan. Motor listrik merupakan piranti yang mampu mengubah energi listrik menjadi energi mekanik, umumnya pengubahan terjadi melalui media elektromagnet. Dalam perkembangannya dikenal beberapa jenis motor listrik mulai dari motor DC, motor AC hingga motor modern yang memerlukan dukungan elektronika daya.(Slamet Riyadi,2018)

\section{HASIL DAN PEMBAHASAN}

\subsection{Hasil}

Hasil dan pembahasan disampaikan secara jelas. Gambar dan tabel yang disertakan dalam makalah dapat diletakkan diantara teks makalah atau sebagai lampiran di akhir makalah. Setiap gambar/grafik/bagan harus format jpg atau sejenisnya. Gambar/grafik/bagan yang tidak berformat jpg menyebabkan layout berantakan. Apabila gambar/grafik/bagan tidak berformat jpg maka panitia akan mengembalikan untuk direvisi sesuai ketentuan tersebut. Masing masing gambar/grafik/bagan dan tabel harus diberi nomor urut.

\subsection{Kondisi Mitra Pengusaha Kerupuk Kemplang}

Hasil dari perancangan mesin dan program pada kegiatan pengabdian dengan mitra usaha kerupuk kemplang "Lebak Keranji" dan "Matahari 222" menghasilkan paket teknologi berupa mesin pemotong kemplang otomatis yang dapat Melakukan pemotongan gelondongan kemplang lebih cepat dan efisien bahan bakar listrik yang dijelaskan gambar 4 dan 5 berikut ini :

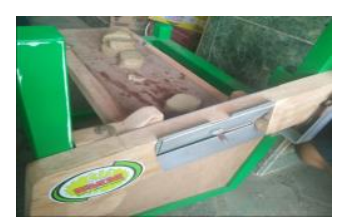

Gambar 4

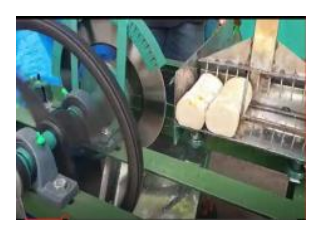

Gambar 5
Pada gambar 4. Alat pemotong gelondongan kemplang manual. Gambar 5 adalah hasil perancangan mesin pemotong kemplang otomatis.

\subsection{Hasil dan Analisis}

Hasil perancangan mesin pemotong kemplang berbasis IoT yang terhubung internet dengan informasi hasil produksi pemtongan dapat dimonitoring menggunakan smartphone dijelaskan pada gambar 6 dan 7 dibawah ini :

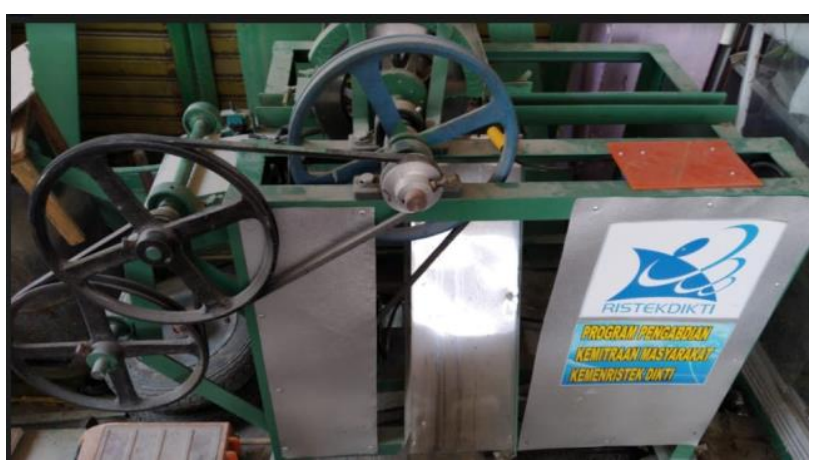

Gambar 6. Mesin Pemotong Kemplang Dengan IoT 


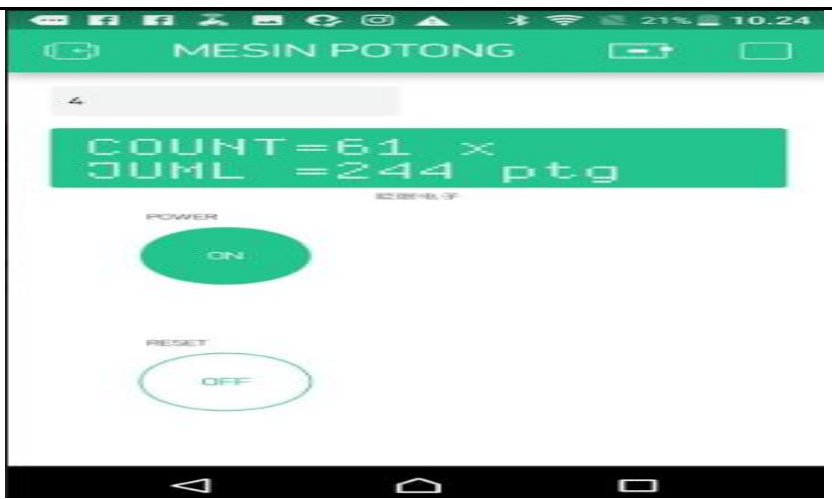

Gambar 7. Hasil Monitoring Produksi Pemotongan Kemplang Dengan Smartphone

Tabel 1. Analisis Hasil Produksi Kerupuk dan Kemplang Ikan sebelum dan setelah dilaksanakan program PKM :

\begin{tabular}{|c|c|c|c|c|c|}
\hline Teknologi & Bahan & $\begin{array}{l}\text { Lama } \\
\text { Waktu }\end{array}$ & $\begin{array}{l}\text { Hasil } \\
\text { Ukuran }\end{array}$ & $\begin{array}{l}\text { Efisiensi } \\
\text { SDM }\end{array}$ & $\begin{array}{l}\text { Kapasitas } \\
\text { Produlusi/Minggu }\end{array}$ \\
\hline $\begin{array}{l}\text { Pemotong } \\
\text { manual }\end{array}$ & $\begin{array}{l}-50 \mathrm{Kg} \\
\text { Tepung } \\
-30 \mathrm{Kg} \\
\text { Ikan }\end{array}$ & $\begin{array}{l}120 \text { sod } \\
180 \text { Menit }\end{array}$ & $\begin{array}{l}>45 \% \\
\text { tidak sama }\end{array}$ & $\begin{array}{l}3 \text { s.d. } 4 \\
\text { orang }\end{array}$ & $\begin{array}{l}1000 \text { sad } 2100 \\
\mathrm{Kg}\end{array}$ \\
\hline $\begin{array}{l}\text { Mesin } \\
\text { Pemotong IoT }\end{array}$ & $\begin{array}{l}-50 \mathrm{Kg} \\
\text { Tepung } \\
-30 \mathrm{Kg} \\
\text { Ikan }\end{array}$ & $\begin{array}{l}15 \text { s.d } 30 \\
\text { Menit }\end{array}$ & $\begin{array}{l}<15 \% \\
\text { tidak sama }\end{array}$ & 1 orang & $\begin{array}{l}2500 \text { s.d. } 4500 \\
\mathrm{Kg}\end{array}$ \\
\hline
\end{tabular}

Dari tabel 1. di atas diperoleh peningkatan nilai jumlah produksi perminggu dengan menggunakan pemotongan menual menghasilkan 1000 s.d $2100 \mathrm{~kg}$ dengan bahan campuran per $50 \mathrm{~kg}$ tepung tapioca dan $30 \mathrm{~kg}$ bahan ikan dengan lama waktu 3 jam dengan ukuran lebih dari 45 persen potongan kemplang tidak sama dengan dikerjakan 3 s.d 4 orang. Dengan menggunakan teknologi mesin pemotong dihasilkan produksi 2500 s.d $4500 \mathrm{~kg}$ perminggu dengan bahan yang sama, dengan lama waktu menyelesaikan pemotongan kurang dari 1 jam dengan ukuran hasil pemotongan lebih dari 80 persen sama hasilnya dan dikerjakan cukup satu 1 (satu) orang . Dengan demikian dihasilkan efisiensi penghematan waktu produksi dan tenaga sumber daya manusia sebesar 3 kali lipat dengan menggunakan teknologi mesin yang dirancang hasil kegiatan program pengabdian ke mitra.

Target luaran yang diinginkan adalah meningkatkan kualitas dan kuantitas jumlah hasil produksi cetakan kerupuk dan kemplang ikan gelondongan. Sehingga hasil produksi kerupuk dan kemplang ikan dapat ditingkatkan, dengan kualitas produksi yang higienis, sehat dan cita rasanya khas dan mengoptimalkan kemampuan calon usaha mitra sehingga dapat bersaing dengan produksi kerupuk dan kemplang ikan di kota Palembang maupun diluar kota sehingga dapat meningkatkan omset bagi usaha mitra.

\section{KESIMPULAN}

Kesimpulan berisi rangkuman hasil kegiatan pengabdian kepada masyarakat dan implikasi dari kegiatan yang dilaksanakan. Hasil kegiatan program pengabdian kemitraan masyarakat ini dengan perapan teknologi mesin pemotong kemplang otomatis ini dapat meningkatkan kualitas dan kuantitas jumlah hasil produksi cetakan kemplang ikan gelondongan. Sehingga hasil produksi kerupuk dan kemplang ikan dapat ditingkatkan, dengan kualitas produksi yang higienis, sehat dan cita rasanya khas dan mengoptimalkan kemampuan calon usaha mitra sehingga dapat bersaing dengan produksi kerupuk dan kemplang ikan di kota Palembang maupun diluar kota sehingga dapat meningkatkan omset bagi usaha mitra.

\section{UCAPAN TERIMAKASIH (Bila ada)}

Ucapan terimakasih disampaikan kepada DRPM Pengabdian Masyarakat Kemenristek DIKTI yang telah mendanai Program Kemitraan Masyarakat No. Kontrak : 036/SP2H/PM/DRPM/III/ 2019.

\section{REFERENSI}

https://sumsel.antaranews.com,2016. Kuliner Palembang kerupuk "kemplang" kurang inovasi,diakses 10 september 2019

Slamet Widodo ,M.Miftakhul Amin , A.Bahri Joni M,(2019).Implementasion Of Calibration in Gas Hazardous Carbon Monoxide, Carbon Dioxide and Methana In Closed Room Using Fuzzy Method. IOP

$$
\text { Teknologi Tepat Guna }
$$


Conf. Series: Journal of Physics: Conf. Series 1167 (2019) 012063

SitiAsmah Daud1, NasrulHumaimi Mahmood2, Pei Ling Leow3 , FauzanKhairiChe Harun4,(2013) Infrared Sensor Rig in Detecting Various Object Shapes. International Journal of Advanced Research in Electrical, Electronics and Instrumentation Engineering, ISSN (Print) : 2320 - 3765

Hiral S. Doshi, Minesh S. Shah, Umair S A. Shaikh(2017), Internet of Things (IoT): Integration of Blynk for Domestic Usability. VJERVishwakarma Journal of Engineering Research,
Volume 1 Issue 4, December 2017.

https://regional.kompas.com ,2010. Orang Belanda Gemar Kemplang Palembang.:dikses 10 September 2019.

Astrid Wulandari,2013 Jurnal Teknik Pertanian Lampung-Vol. 2, No. 2: 105 - 114

Handi,2019. Jurnal Pengembangan Teknologi Informasi dan Ilmu Komputer Vol. 3, No. 4, April 2019, hlm. 3258-3265

Slamet Riyadi,2018. Jurnal PRAXIS | Vol. 1 | No. 1 | September 2018 